\title{
Small-Scale Irrigation and Production Efficiency among Vegetable Farmers in the Eastern Cape Province of South Africa: The DEA Approach
}

\author{
Douglas Kibirige (Corresponding Author) \\ Douglas Kibirige $(\mathrm{PhD})$, Senior Lecturer at the Department of Agricultural Economics and \\ Management, Faculty of Agriculture, University of Eswatini, Eswatini. \\ E-mail: kibirige@uniswa.sz, kibirigedouglas@gmail.com \\ Ajay S. Singh \\ Ajay S. Singh (PhD), Senior Lecturer at the Department of Agricultural Economics and \\ Management, Faculty of Agriculture, University of Eswatini, Eswatini. \\ E-mail: asingh@uniswa.sz, singhas64@hotmail.com

\section{Lovemore M. Rugube} \\ Lovemore M. Rugube (PhD), Senior Lecturer at the Department of Agricultural Economics \\ and Management, Faculty of Agriculture, University of Eswatini, Eswatini. \\ E-mail: ruguubelm@gmail.com
}

Received: Feb. 28, 2019

doi:10.5296/jas.v7i1.14564
Accepted: Mar. 19, 2019 Published: Mar. 26, 2019

URL: https://doi.org/10.5296/jas.v7i1.14564

\begin{abstract}
Despite the establishment and revitalization of small-scale irrigation schemes, input subsidies and tractor hire schemes in the rural Eastern Cape Province of South Africa productivity among small-scale farmers is recorded low and anticipated to decline. For survival, small-scale farmers have resorted to cultivating high value crops including vegetables. However, their vegetable productivity is far less than the estimated potential yields, and information regarding their production efficiency is limited. Therefore, this study was aimed at determining farmer's production efficiency to generate meaningful information necessary for designing feasible pro-poor policies aimed at catalysing increased the productivity and rural household incomes. The study was carried out at Qamata and Tyefu irrigation schemes, and approximately 158 farmers were interviewed. The Data Envelopment Analysis (DEA) approach was used to generate results. The findings in this article indicated that most farmers are old aged with low literacy levels. Farmers were also allocating few hectares of land for cabbage production with far less application of fertilizers and pesticides compared to the recommended amounts. Farmers at Qamata and Tyefu irrigation schemes are technically,
\end{abstract}


allocatively and economically efficient at $98 \%, 72 \%$ and $77 \%$ level, respectively. Thus, for improving the productivity, farmers need to maintain the same technologies and adjust on the amounts of fertilizers, seeds and pesticides used for improving allocative and economic efficiency. Results suggested that this can be achieved through encouraging more youth participation in farming, improved input-agronomic and agribusiness skills, catalysing processes of land reforms, and construction of more dams.

Keywords: smallholder farmers, irrigation, data envelopment analysis, technical efficiency, allocative efficiency, economic efficiency, cabbage production

\section{Introduction}

The importance of irrigation is informed by international experience (Montilla-López et al., 2016). Lipton et al. (2003) indicated that, regions like Eastern Asia and the Pacific, and North Africa and Middle East have experienced a greater poverty reduction, increased food security and employment because they established some large proportions of irrigated land for crop production. Establishment of irrigation schemes in semi-arid and areas prone to prolonged droughts in the rural communities of former homelands of South Africa was viewed as one of the development pathways for increased agricultural productivity, improved food security, increased employment and poverty alleviation (Van Averbeke et al., 2011; Kibirige, 2013; DAFF, 2015; Montilla-López et al., 2016).

On realization of water scarcity, many irrigation schemes were established in the Transkei and Ciskei former homelands of the current Eastern Cape Province during the 1960s and 1970s. However, most of the established irrigations schemes were unsustainable due to numerous challenges (Van der Horst and Hebinck, 2017). In quest to revive the failed irrigation schemes, the government of South Africa embarked on revitalization of these schemes which began in 1994 through the introduction of canal irrigation schemes in the Eastern Cape. Irrigation schemes were established to stimulate economic growth and rural development (Kibirige, 2013; DAFF, 2015). These irrigation schemes included Ncora, Keiskammahoek, Tyefu, Shiloh and Zanyokwe. Despite these developments, smallholder farms still faced low outputs and productivity (Van Averbeke et al., 2011). Moreover, the results in the Eastern Cape Province have not matched the international experience (Kodua-Agyekum, 2009; Manona et al., 2010; Averbeke et al., 2011; DAFF, 2015). For example, most rural communities like at Qamata and Tyefu irrigation schemes are still faced with high levels of poverty affecting $76 \%$ and $79.9 \%$ of the population, respectively (InsikaYethu Municipality, 2008; Ngqushwa Municipality, 2007; Kibirige, 2013).

According to Cousin (2013), several studies have indicated underutilization of communal arable land including irrigation schemes. The same author cited Andrew et al. (2003) indicating that small-scale farmers including irrigators are faced with numerous challenges like shortages of labour, capital and income to purchase inputs; poor supply of inputs and tractor services; poor soil fertility; high risks of crop damage by livestock due to lack of fencing; lack of agricultural markets and high competition from large-scale commercial farming, and the weakening of social bond resulting in declining cooperative activities. Most irrigations scheme facilities were old and hence reducing on their efficiency. 
On realising farmers' challenges, the government of South Africa has continued its efforts of revitalizing irrigation schemes and initiating some agricultural support programmes like Siyazondla (Homestead food gardening), Siyakhula (Small-scale farmers) and Massive Food Production Programme (MFPP) (GoSA Information, 2008; Fanadzo and Ncube, 2018). These programmes are in line with the agrarian reform policy and provide farmers with inputs subsidises like seed, fertilizers and farm implements. Though the programmes are trying to ease access to land, water and variable inputs, farmers' crop production is recorded low and thought to decline more at an increasing rate (Tregurtha, 2009; Fay, 2011). Tregurtha (2009) and Fay (2011) identified more anticipated factors resulting in farmers' low productivity and these are inefficient utilization of land, water and other inputs, and low adoption of new technologies.

Kibirige (2013) cited Farrell (1957) defining efficiency as the ability to produce a given level of output at the lowest cost. Efficiency can be divided into two concepts, the technical and allocative efficiency. Technical efficiency is the ability of the farm to produce a maximum level of output given a similar level of production inputs. Allocative efficiency literally can be defined as generating of output with the least cost of production to obtain maximum profits. Economic efficiency is a product of both allocative and technical efficiency and it is achieved when the producer combines resources in the least combination to generate maximum output as well as ensuring least cost to obtain maximum revenue (Chukwuji et al., 2006). Therefore, for increased productivity and profitability, farmers need to improve on the management practices through trainings and transfer of knowledge and skills from less to more efficient farmers or increase on adoption of new available technologies (Padilla-Fernandez and Nuthall, 2001).

\section{Methodology}

\subsection{Field Methods}

This study was purposively carried out at Qamata and Tyefu located in the Eastern Cape Province of South Africa to assess the impact of irrigation schemes on farmers' production efficiency. Cabbage is among vegetable crops grown by small-scale farmers especially during winter for both home consumption and incomes. Primary survey data was collected through administering structured questions and physical observations and used to generate results of this study. Farm/farmer characteristics, farm production and market related data was collected. One hundred eight and 50 smallholder farmers were interviewed in Qamata and Tyefu communities, respectively, making a total sample of 158 respondents.

\subsection{Analytical Methods}

This article employed the Data Envelopment Analysis approach. This approach is one of the most common non-parametric methods used to estimate production efficiencies (Coelli, 1996; Speelman et al., 2007; and Lemba et al., 2012). Following Coelli (1996), Speelman et al. (2007) and Lemba et al. (2012), one of the principle assumptions of the DEA model is that there is a linear relationship between $K$ farm input and farm output $M$ of each of $N$ farms. 
The input data $\left(X_{i}\right)$ from each individual farmer i and output data $\left(Y_{i}\right)$ from each individual farmer is arranged in a column vector form of $X_{\hat{i}}$ and $Y_{\tilde{i}}$, respectively. In this article, the variables presented in the input matrix $X_{i j}$ included size of land cultivated, seeds quantity, fertilizer quantity, agro-chemicals like quantities of pesticide, herbicides used, and the value of capital invested, whereas the output matrix $Y_{i j}$ included the output quantity of $i^{\text {th }}$ farm $\& j^{\text {th }}$ crop enterprise. Following earlier studies carried out by Speelman et al. (2007) and Lemba et al. (2012), the DEA model was presented by the linear programing equations used to establish the relationship between input and output, thereby estimating production efficiency. The linear programming equations can be presented as:

$$
\operatorname{Min}_{\lambda}
$$

Subject to:

$$
\begin{gathered}
-Y_{i j}+Y \lambda \geq 0, \\
\theta X_{i j}-X \lambda \geq 0, \\
N 1^{y} \lambda=1_{y} \\
\lambda \geq 0
\end{gathered}
$$

Where

$\theta=$ scalar, $N 1=N x 1$ vector of ones, and $\lambda=$ vector of constants. $\theta$ value $=$ technical efficiency score for a given farm i. In most cases, the value of $\theta$ is greater than zero but less than one or equals to one. The farm is reported to be $100 \%$ efficient if the value of $\theta$ equals to one and the score value is located on the frontier line, and if there is a reducing trend in the value of $\theta$ from one towards zero then the farm is reported to be inefficient. The Variable Returns to Scale (VRS) represented in the equation as $N 1^{z} \lambda=1$ assumes a non-linear relationship between the input and output, thus referred to as convexity constraint. If this condition is not expressed in the linear programming equation, then efficiency is estimated under the Constant Return to scale (CRS) specifications, implying the frontier is considered to be a straight diagonal curve. The equation can further be expressed using input cost 


\section{Macrothink}

minimization to maximize output according to Färe et al. (1994). To estimate efficiency for a selected individual variable input $\mathrm{k}$ for the $\mathrm{i}^{\text {th }}$ farm, the following linear programme equation can be used.

$$
\operatorname{Min}_{\theta \lambda} \theta_{k}
$$

Subject to

$$
\begin{aligned}
& -Y_{i}+Y \lambda \geq 0, \\
& \theta_{k} X_{i}^{k}-X^{k} \lambda \geq 0, \\
& X_{i}^{n-k}-X^{n-k} \lambda \geq 0, \\
& N 1^{s} \lambda=1_{x} \\
& \lambda \geq 0,
\end{aligned}
$$

Where; $\theta_{k}=$ input $\mathrm{k}$ sub-vector T.E for farm i. The second constraint with terms $X_{\bar{i}}^{k}$ and $X^{k}$ includes only the $K^{t h}$ input and in the third constraint which contains terms $X_{i}^{n-k}$ and $X^{n-k}$ it excludes (thus, $n-k$ ) the $K^{\text {th }}$ input. Other variables in this equation are defined in equation 1.

According to Coelli (1996), when estimating efficiency using the DEA model, there are two scale assumptions generally employed, namely, the constant returns to scale (CRS), and variable returns to scale (VRS). Farmers operate at different levels and this can be demonstrated graphically based on whether or not observed levels along the frontier corresponding to a particular returns to scale. The behaviour of the curves generated by the DEA approaches depends on the scale assumptions considered when modelling. The VRS consider both increased and decreased returns to scale while CRS assumes that output changes by the same proportion with a change in inputs employed. Further, VRS recognise variation in technologies (Coelli, 1996).

Based on the assumptions that inputs are fixed and farms are producing optimally, figure 1 presents both the CRS and VRS frontiers. Assuming constant returns to scale, all farms operating below point $\mathrm{C}$ on the CRS frontier are considered inefficient and underutilizing resources. Assuming variable returns to scale, all farms operating below the VRS frontier defined by points A C D are considered inefficient. Thus, a farm operating at point B is considered in efficient. 


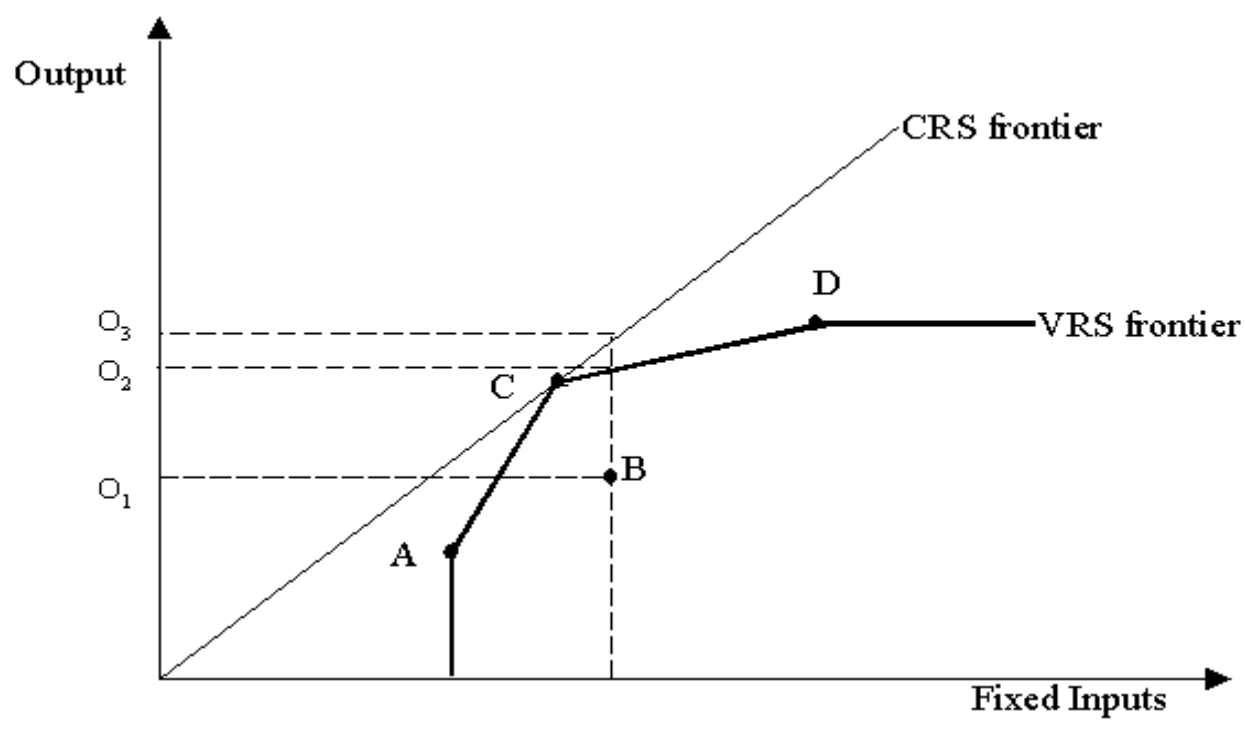

Figure 1. CRS and VRS Frontier

Source: Coelli (1996)

\section{Results}

In his study, Kibirige (2013) indicated that most small-scale farming is dominated by male farmers $(69 \%)$ in the study area and this may be attributed to loss of jobs through retrenchment policies and retirement. Further, Kodua-Agyekum (2009) indicated that over $90 \%$ farm plots on irrigation schemes and dry land were allocated to men biased towards the African cultural rules and norms which deny women's legal rights to own such a crucial agricultural resource. 
Table 1. Demographic characteristics of smallholder farmers the study area $(n=158)$

Characteristics Description Percentage

\section{Non-continuous variables}

Sex of household head

Male

Female

Level of formal education

Non

Primary

Secondary

Tertiary

01

Major occupation

Farmer

92

Self-employed

05

Civil servant

03

\section{Continuous variables}

\begin{tabular}{lcc}
\hline & $\begin{array}{c}\text { Average mean } \\
\text { value }\end{array}$ & $\begin{array}{c}\text { Standard } \\
\text { deviation }\end{array}$ \\
Household size & 4.469 & 2.344 \\
Age of farmer (Years) & 61.066 & 12.703 \\
Years spent in school & 5.422 & 4.358 \\
Faming experience (Years) & 13.017 & 11.928 \\
\hline
\end{tabular}

Source: Kibirige (2013).

Results in Table 1 further suggests that the largest proportion of farmers had some education, mostly up to 5 years of primary school education (42\%) although a handful did not have any education at all $(28 \%)$ and very few had post-secondary education $(1 \%)$. This implies that most household heads depend on the local language to access farm information especially through their fellow farmers. Education level of the farmer is crucial in sourcing for 
agricultural information and adoption of new technologies. Different farm reading materials, labels placed on input packages and conducting of trainings are presented using English. The household size averaged approximately 5 persons Household size in most rural villages of Sub-Saharan Africa is known to be a source of farm and off-farm labour (Kibirige et al., 2010).

Most farmers (92\%) interviewed considered farming as their major occupation, an indication of the endemic unemployment situation among the Qamata and Tyefu population. Data presented in Table 1 indicated that the average age of the household head among smallholder famers interviewed was about 61 years. This indicates that farmers at Qamata and Tyefu irrigation scheme areas may be less productive since their age is far above the youthful productive stage as defined by Ogundele and Okoruwa (2006). Increased number of farmers within this age bracket may be a reflection of more retrenched and retired formal employees who take on farming as their source of livelihood for survival (Kodua-Agyekum, 2009). According to Kibirige (2013), results indicated that the average farming experience of smallholder farmers was approximately 13 years. Although age and farm experience are considered to be interrelated, age in most cases is associated with increasing farm output in terms of energy for farm labour at a decreasing rate (Bagamba, 2007).

\section{Input Use in Cabbage Production among Small-scale Farmers in the Study Area}

Some of the major inputs used by small-scale farmers in the study area include land, irrigation water, seed, fertilizers and pesticides as presented in Table 2. On average, farmers grow cabbage on less than one hectare (0.16ha). They plant about $510 \mathrm{~g} / \mathrm{ha}$ of cabbage seed on average with approximately $41 \mathrm{~kg} / \mathrm{ha}$ of fertilizers and 1.38 litre/ha of pesticide, respectively. Cabbage can hardly survive both in winter and summer seasons without irrigation in the Eastern Cape Province of South Africa. Therefore, small-scale farmers irrigate their plots about 148 times/ha/season. Although results indicate that farmers' cabbage seed planting rate was within the recommended rate ranging from 0.50 to $2 \mathrm{Kg} / \mathrm{ha}$ for direct seeding, they applied far less fertilizers than the recommended rate ranging between 500 and $1000 \mathrm{Kg} / \mathrm{ha}$ in cabbage production (Allemann and Young, 2008). 
Table 2. Input use in Cabbage production among Small-scale Farmers

Variables

land under cabbage production (ha)

Cabbage seeds planted per ha (Kg/ha)

Fertilizer applied per ha of cabbage $(\mathrm{Kg} / \mathrm{ha})$

Pesticide applied per ha of cabbage (L/ha)

Number of irrigations/season/ha
Average mean Standard deviation
0.23

1.12

41.12

95.81

1.38

7.09

147.68

Source: Kibirige (2013): ha = hectares, $K g=$ Kilograms, $L=$ Litres.

\section{Profitability of Cabbage Enterprises}

The results presented in Table 3 indicated that the mean farmers' cabbage yields was about 974 with approximated average total revenue and total variable cost of production of R4431/ha and of R661/ha, respectively. The approximated average gross margins generated from cabbage production as reported by Kibirige (2013) were R3770/ha and only about 22\% of cabbage produced is sold in the market.

Table 3. Profitability of Cabbage Enterprises among Smallholders $(\mathrm{n}=158)$

\begin{tabular}{lccc}
\hline Variables & Description & Mean & $\begin{array}{c}\text { Standard } \\
\text { deviation }\end{array}$ \\
\hline Cabbage yield & Heads/ha & 974.09 & 2790.30 \\
Total revenue from cabbage & Rand/ha & 4431.245 & 15128.99 \\
Total cost for cabbage production & Rand/ha & 661.29 & 1684.24 \\
Gross margins for cabbage & Rand/ha & 3769.960 & 15022.47 \\
Commercialization index for cabbage & Ratio & 0.22 & 0.37 \\
\hline
\end{tabular}

Source: Kibirige (2013). Where, ha $=$ hectares, Commercialization index ratio $=$ Quantity marketed of a given crop divided by total quantity harvested of the same crop.

According to Allemann and Young (2008), the recommended cabbage yield in terms of number of cabbage plants per hectare ranges between 40000 and 45000 heads/ha, however, findings in this study indicated that smallholder farmers were planting far less (about 974 
heads/ha) than the recommended amount. This is probably because smallholder farmers in the Eastern Cape Province apply less agro-chemicals which are important for fertility, pesticides and weed control and hence resulting in low productivity. The less use of fertilizers, herbicides and pesticide may be due to lack of investment capital and lack of access to farmer friendly credit facilities to purchase these inputs.

\section{Estimating the Production Efficiency of Cabbage Enterprise by DEA}

A study carried out by Kibirige (2013) generated results using the DEAP (Version 2.1) statistical software as displayed in Table 4. The Variable Returns to Scale (VRS) scores of smallholders under study indicated that all are technically efficiency in cabbage production at 98\% level. Further, results suggest that smallholders' scale efficiency and the CRS indices were low at 0.49 and 0.47 , respectively, and closely related. The relatively correlated scores of both the scale efficiency and CRS seem to suggest that farms under study were not operating at the same optimal scale/frontier. Thus, this qualifies the VRS scores as the viable estimate to consider in such situations. Results further indicate that there are approximately $98.7 \%$ of farmers operating at increasing returns to scale, respectively.

Farmers' technical, allocative and economic efficiency scores were generated using available data related to amounts of cabbage seeds planted in $\mathrm{Kg} / \mathrm{ha}$, fertilizer in $\mathrm{Kg} / \mathrm{ha}$ and litres $(\mathrm{Kg})$ of pesticides applied per hectare. According to Kibirige (2013), generated results revealed the mean allocative, technical and economic efficiency scores were approximately 0.72, 0.94 and 0.77 , respectively. Based on the allocative efficiency scores, for profit maximization at least input cost combination, farmers had to reduce on costs incurred in the use of cabbage seed, fertilizer and pesticide by $28 \%$. In order to maximize output using the same available inputs and technology, smallholder irrigators have to increase on their technical efficiency by about $6 \%$.

Table 4. Estimating Farmers' Cabbage Production Efficiency: DEA

Variables

Variable returns to scale (VRS) technical efficiency

Scale technical efficiency

Constant returns to scale technical efficiency

Allocative efficiency (A.E)

Technical efficiency (T.E)

Economic efficiency (E.E)
Mean

Standard deviation

0.981

0.081

0.485

0.158

0.469

0.133

0.719

0.300

0.939

0.158

0.765

0.318

Source: Kibirige (2013). 


\section{Conclusions and Recommendations}

On average, statistics in this article indicate most farmers are aged about 61 years old with as low as approximately 5 years of formal education. This implies that there are very few youth aged farmers. The low youth participation in farming may result in increased loss of sustainable indigenous knowledge and skills in farming, increased unemployment rates and increased food insecurity and hence leading to skyrocketing and wide spread poverty levels in the Eastern Cape Province. This calls for more innovations and initiatives that attracts youths and equip them with formal education and financial support to ease their participation in farming.

Farmers in the selected study area seem to allocate a few acres of land and apply far less fertilizers and pesticides in cabbage production compared to the recommended amounts. Thus, given the availability of cabbage markets and increasing demand for the same produce, farmers need to be encouraged to expand individual acreage under cabbage production through more appropriate and feasible pro-poor rural land reforms. Further, there is need to improve on farmers' easy access to farm inputs including fertilizers and pesticides through improved subsidies and input credits, and improved distribution of input dealers nearer to farms. Improved access to inputs may also call for improved networking between farmers, agricultural input dealers and finance institutions like banks, micro-finance and Savings and Credit Cooperatives (SACCOs), and revolving group funds.

The major sources of water for crop production among farmers understudy were reported as direct rainwater and dam water converged from rivers. Since most farmers interviewed are resource-poor, direct rainwater was viewed as the cheapest means of watering their crops in addition to communal dams. This is an indication that farmers lacked rainwater harvest technologies and less irrigation equipment necessary to store and transport water to their gardens, respectively. Therefore, it is of great importance that the government and other support organisations to fund projects that promote sustainable water use and establishment of rainwater harvest technologies and irrigation schemes.

The findings of this study indicated that farmers earn low net gross margins from cabbage production. The findings further indicated that farmers were generally technically efficient, although allocatively and economically inefficient. For farmers' efficient utilization of irrigation water, results indicate that they were technically inefficiently. Thus, for more profitable cabbage production, farmers should retain the same technologies with exception of water utilization and consider accurate application of purchased inputs in terms of amounts of fertilizers and pesticides applied. To improve on the accurate amounts of inputs applied, more agronomic extension service trainings need to be emphasised, and farmers trained in business management skills for improved participation in markets and hence increased household incomes, allocative and economic efficiency. These trainings can be provided by the government, NGOs and internal social networks. 


\section{References}

Allemann, L., \& Young, B. W. (2008), Vegetable Production in a Nutshell: Directorate Agriculture Information Service, Department of Agriculture in Cooperation with KwaZulu-Natal Department of Agriculture and Environmental Affairs: Printed and Published by Department of Agriculture, Pretoria, South Africa. https://doi.org/10.2166/wp.2005.0007

Backeberg, G. R. (2005). Water Institutional Reforms in South Africa, Water Policy, 7, 107-123; Water Research Commission, Pretoria, South Africa. https://doi.org/10.2166/wp.2005.0007

Bagamba, F. (2007). Market access and agricultural production: The case of banana production in Uganda, PhD Thesis, Wageningen University, Netherlands; ISBN 90-8504-633-5.

Chukwuji, C. O., Inoni, O. E., Ogisi, O. D., \& Oyaide, W. J. (2006). A Quantitative Determination of Allocative Efficiency in Broiler Production in Delta State, Nigeria. Department of Agricultural Economics and Extension, Delta State University, Asaba Campus, Asaba. Delta State, Nigeria: Agriculturae Conspectus Scientificus, 71(1), 21-26.

Coelli, T. J. (1996). A guide to DEAP Version 2.1: A Data Envelopment Analysis (Computer) Program. CEPA Working Papers No.8/96, Department of Econometrics, University of New England, Australia. ISSN 1 327-435X; ISBN.1 863894969.

Cousins, B. (2013). Smallholder Irrigation Schemes, Agrarian Reform and 'Accumulation from Above and from Below' in South Africa, Journal of Agrarian Change, 13(1), 116-139. https://doi.org/10.1111/joac.12000

Department of Agriculture, Forestry and Fisheries (DAFF)-Republic of South Africa, (2015). Irrigation Strategy for South Africa

Fanadzo, M., \& Ncube, B. (2018). Review-Challenges and opportunities for revitalising smallholder irrigation schemes in South Africa. Water SA, 44(3), July 2018.

https://doi.org/10.4314/wsa.v44i3.11

Färe, R., Grosskopf, S., \& Lovell, C. A. K. (1994). Production Frontiers. Cambridge, Cambridge University Press.

Farrel, M. J. (1957). The measurement of productivity efficiency. Journal of Royal Statistical Society A120, 253-281. https://doi.org/10.2307/2343100

Fay, D. (2011). Cultivators in action, Siyazondla inaction? Trends and potential in homestead cultivation in rural Mbhashe Municipality", Department of Anthropology, University of California, Riverside.

IntsikaYethu Municipality, (2008). Report on housing sector plan 2008 to 2012, Prepared By: Tshani Consulting; Wanklin \&Naidoo Development Specialists.

Kibirige, D. (2013). The impact of human dimensions on smallholder farming in the Eastern Cape Province of South Africa", PhD thesis, University of Fort Hare, Alice Campus, South Africa 
Kibirige, D., Kiiza, B., \& Elepu, G. (2010). Analysis of Technical and Allocative Efficiency of Agricultural Productivity Enhancement Program on Maize Farmers; Masindi District (U), monogram Book; ISBN: 978-3-8383-7163-4, Published by LAP-Lambert Academic Publishers and printed in the USA and UK.

Kodua-Agyekum, C. (2009). The transfer of technology to the rural poor: The case of Qamata Irrigation Scheme in the Eastern Cape Province of South Africa. Phd Thesis, Faculty of Humanities, Development and Social Sciences, University of Kwazulu-Natal, South Africa.

Lemba, J., D'Haese, M., D'Haese, L., Frija, A., \& Speelman, S. (2012). Comparing the technical efficiency of farms benefiting from different agricultural interventions in Kenya's drylands, Development Southern Africa, 29(2), 287-301, Publisher: Routledge. https://doi.org/10.1080/0376835X.2012.675698

Lipton, M., Litchfield, J., Blackman, R., De Zoysa, D., Qureshy, L., \&Waddington, H. (2003). Preliminary review of the impact of irrigation on poverty with special emphasis on Asia, Poverty research unit at Sussex: University of Sussex: AGL/MISC/34/2003: Land and Water Development Division; Water Resources, Development and Management Service; FAO, Rome, 2003.

Manona, S., Denison, J., Van Averbeke, W., \&Masiya, T. (2010). Proposed Land Tenure and Land Administration Interventions to Increase Productivity on Smallholder Irrigation Schemes in South Africa, Paper presented at the conference on 'Overcoming inequality and structural poverty in South Africa: towards inclusive growth and development', PLAAS, SPII and Isandla Institute, Johannesburg.

Montilla-López, M., Gutiérrez-Martín, N. C., \& Gómez-Limón, J. A. (2016). A Review Water Banks: What Have We Learnt from the International Experience?; Water-Open Access Journal

Ngqushwa, M. (2007). Integrated Development Plan; Ngqushwa Municipality Reviewed IDP, 2006/07, the Eastern Cape Province of South Africa.

Ogundele, O. O., \& Okoruwa, O. V. (2006). Techical efficiency differential in rice production technologies in Nigeria”, Africa Research Consortium, Research paper 154.

Padilla-Fernandez, M. D., \& Nuthall, P. (2001). Farmers' goals and efficiency in the production of sugar cane: The Philippine case, Farm and Horticultural Management Group Lincoln University, ISSN 1174-8796, Research Report 07/2001.

Samuel, T. L. L. (2009). Lack of freshwater throughout the world", Evergreen State College. http://academic.evergreen.edu/g/grossmaz/LARSENST/.

Sishuta, B. (2005). Small-scale Irrigation Development for sustainable Rural Development: A case study of the Tyhefu Irrigation Scheme, African Sociological Review, 9(2), 184-206.

South African Government Information, (2008). Programmes in the Eastern Cape, www.info.gov.za/issues/govtprog/ecape.htm: 27th August 2008. 


\section{Al Macrothink}

Journal of Agricultural Studies

ISSN 2166-0379 2019, Vol. 7, No. 1

Speelman, S., D’Haese, M., Buysse, J., \& D’Haese, L. (2007). Technical efficiency of water use and its determinants study at small scale irrigation schemes in North-West Province, South Africa, Paper prepared for presentation at the $106^{\text {th }}$ seminar of the EAAE; Pro-poor development in low income countries: Food, agriculture, trade, and environment; 25-27 October 2007 - Montpellier, France.

Tregurtha, N. (2009). Review of the Eastern Cape's Siyakhula/Massive maize project, Trade and Industrial Policy Strategies.

Van Averbeke, W., Denison, J., \& Mnkeni, P. N. S. (2011). Smallholder Irrigation Schemes in South Africa: A review of Knowledge Generated by the Water Research Commission, Centre for Organic and Smallholder Agriculture, website http://www.wrc.org.za; ISSN 0378 4738, Water SA, 37(5), WRC

Van der Horst, B., \& Paul, H. (2017). 'Irrigation by night' in the Eastern Cape, South Africa, Water SA, 43(1). https://doi.org/10.4314/wsa.v43i1.05

\section{Copyright Disclaimer}

Copyright for this article is retained by the author(s), with first publication rights granted to the journal.

This is an open-access article distributed under the terms and conditions of the Creative Commons Attribution license (http://creativecommons.org/licenses/by/4.0/). 